\title{
Study of Socialist Social Management with Chinese Characteristics
}

\author{
Qin Shi \\ Department of Public Health, Xi'an Medical University, Xi'an, Shaanxi, 710021
}

Keywords: Socialist, Social Management, Chinese Characteristics

\begin{abstract}
Social orderly operation can not be separated from scientific management. However, under the highly centralized traditional system, social management has not received the attention it deserves. Since the reform and opening up, with the transition of the economic system and social transformation, the unit system has been modest, the social mobility has accelerated, social organizations have emerged, new social issues and social affairs have increased, and the traditional social management system based on the unit system has been unsustainable We urgently need to establish a social management model that is compatible with the development of the socialist market economy and the building of a harmonious socialist society.
\end{abstract}

\section{Introduction}

Social orderly operation can not be separated from scientific management. Social management is practice, but also scientific theory. "It is the result of social development and scientific development that putting social administration as an awareness issue and operating in accordance with certain rules in practice is the result of social development and the more developed the society and the more it requires scientific social management, Proved for the practice of social development. The main body, content and mode of social management are closely related to the social formation, the state of productive forces, social structure and political and cultural traditions. Therefore, different countries, different systems, different periods, and even the same country in different periods, social management is very different. The social management of socialism with Chinese characteristics 2 is a new topic put forward by the CPC to lead the people of all nationalities throughout the country in deepening their understanding of what socialism is and how to build socialism during the practice and exploration of the reform and opening up. Practice has just started, the theory has not yet finalized. Based on the basic concepts, this article attempts to systematically analyze the reasons why socialism with Chinese characteristics come from, who should manage, what to manage, how to manage, what are the main problems now and what are the underlying causes and how to improve social management. With a view to promoting in-depth study of social management law and building a socialist harmonious society to provide valuable theoretical analysis and practical strategies.

\section{Subjects and Objects of Socialist Social Management with Chinese Characteristics}

The unique role of the Communist Party of China in social integration is not only reflected in the ability to surpass various social interests, to integrate interests, but also to use social ideology for social integration. The main function of ideological social integration is to build a harmonious and cohesive social environment and atmosphere for social development by building a value system universally accepted by society. This requires that ideology must be broadly inclusive. Inclusiveness has two meanings. First, it has a broad boundary, can integrate many different values in one ideological system. Second, it has more room to provide theory for the broadest possible choice of policy Support. "(4) Our party uses Marxism as its guiding ideology and its dominant ideology. Leading is not the only one. Adhering to the guiding position of Marxism does not exclude the diversification of social ideas and concepts. Marxism has always been developing mutual agitation and struggles with various ideological concepts. Respecting differences and inclusiveness means adhering to and developing The proper meaning of Marxism. (5) The public's approval of the party's 
ideology depends not only on the party's ability to lead social practice under the guidance of such ideology, but also on the ability of this ideology to lead social trends of thought. Under the conditions of a market economy, changes in the mode of production inevitably lead to changes in ideological concepts. At present, our country is experiencing profound historical changes. As the mainstream ideology continues to develop, various ideological and cultural concepts are intertwined and collide with each other. How to make the mainstream ideology reflect the interests, wishes and demands of all classes of people and correctly guide various ideological and cultural concepts on the basis of upholding their basic values so as to inspire the community to create vitality to the maximum extent is the construction of socialist ideology in the new era An important issue. Francis Fukuyama, in his analysis of institutional capabilities, said: "Although cultural rules change over time, it is much more difficult for them to change their public policies." (1) The socialist core value system is a socialist one The essence of reflection. Only when the Party insists on leading and integrating social ideological trends with the socialist core value system, expanding social identity in respect of differences and forming ideological consensus on inclusiveness and diversity can the party more effectively reflect the interest demands of different social strata and groups and at the level of values Eliminate estrangement, resolve contradictions, and create a favorable environment and atmosphere for strengthening social management and building a harmonious socialist society.

\section{Socialism with Chinese characteristics Social management of the main problems currently facing}

In the Soviet Union, socialist political management was once seen as the management of the entire society including the fields of economy, society, politics and spiritual thought. This kind of view is a misunderstanding of socialism and a misunderstanding of political management. It neither sees the role of market mechanism under socialism nor the ability of the society to manage itself in a way that is beyond the political management. Political management is understood as superfluous and over-centralized management, thus overwhelming the significance of political management in macro-coordination. (1) This concept has had a far-reaching impact on our country. Up till now, people have not completely freed themselves from this concept and have caused the goal and result of the government in social management to be disconnected.

The social management system in the transitional period of the old and the new system is in the triple tension of "the traditional reliance on deconstruction and one system transformation", showing obvious transitional features. It not only shows the imperfect systems and mechanisms of social management, but also the imperfect laws and regulations as well as the systems, mechanisms and laws and regulations supporting the social management.

Since the reform and opening up, China has carried out six times the institutional reform of the State Council, but mostly according to the requirements of the reform of the economic system and design of the content of reform. This kind of reform method has made our country's management of economic affairs more and more mature, but it lags far behind the management experience and ability in social affairs. If we fail to timely and effectively reform the social management system, it will inevitably affect the deepening of economic restructuring. In 2005, the fifth State Council institutional reform conducted under the background of accession to the World Trade Organization made it clear that under the conditions of a socialist market economy, government functions are mainly economic regulation, market supervision, social management and public service. This reform further promoted the transformation of government functions. From the long-term focus on economic functions to more prominent social management and public service functions, there needs to be a process. In this process, the government has been offsided, misplaced and absent from time to time. It has also shown that the service awareness is not strong enough and the management methods and methods are backward.

The goal of social management is to coordinate the relations of interests, resolve social conflicts, solve social problems, and safeguard the orderly operation of the society so as to improve the quality of life of members of the society and form a concerted effort to build a harmonious socialist 
society. Since the reform and opening up, the deepening of various reforms and the adjustment of the pattern of interests have triggered and accumulated a great deal of social conflicts. The increase of social instability has posed a severe challenge to the unsolved social management system in our country. At present, these factors are mainly manifested as people's livelihood problems and corruption problems. Frequent mass incidents are the result of the interaction of these factors.

\section{Perfect Strategy of Socialist Management with Chinese Characteristics}

People-oriented is the core concept of socialism management with Chinese characteristics. At present, the concept of putting people first in social management has two major meanings. Build a new type of relationship between government and society that meets the requirements of a socialist market economy, and establish a social management network in which the government regulatory mechanism is interconnected with the social regulatory mechanisms, the administrative functions of the government are complementary to the functions of social autonomy, and the regulatory forces of the government interact with the social regulation forces. The system of effective coverage and overall management of the entire society is an inevitable requirement for building a harmonious socialist society.

The "Decision on Strengthening the Building of the Party's Ability to Govern" adopted by the Fourth Plenary Session of the 16th CPC Central Committee clearly states that "innovation in social management system should be promoted." The social management system is the institutionalized manifestation of the pattern or mode of social management, or the social management pattern or mode is the finalization of the social management system. Social management system innovation involves all aspects. According to the basic principles of Marxist dialectical materialism, we must innovate the social management system at a specific historical stage. We must combine the characteristics of the times with the basic national conditions and determine the key tasks of innovation in social management system. The scholars have different opinions on what is the key task of innovation in social management system. Hou Yan believes that promoting social management system innovation should grasp the four key tasks, namely, speeding up the government reform, speeding up institutional reform, vigorously foster the development of social organizations, and vigorously strengthen community building and management. (1) Dai Junliang believes that the focus of social management system reform and innovation should be placed on social security, culture and education, health care, social security, environmental protection, morality, social services and other social welfare undertakings. (2) Chen Fujin pointed out: To establish and perfect a social management system that is compatible with the construction of a harmonious society, we should now make the following four points: First, establish and improve a social management pattern in which party leaders are responsible, government is responsible, social coordination and public participation. The second is to establish and perfect the social service system of grass-roots urban and rural organizations that coordinate interests, resolve conflicts and solve problems. Third, establish and improve a social monitoring network that provides services, reflects appeals and standardizes behaviors. Fourth, we must establish and improve a social security system that links social insurance, social assistance, social welfare and philanthropy. (3) Ding Yuanzhu believes that at present China's social management system innovation needs to establish and perfect four mechanisms, namely social development comprehensive decision-making and implementation mechanism, social impact assessment mechanism, social safety net mechanism and social risk management mechanism. (4) He Zengke and others proposed that the social management system reform has eight key tasks, namely, the reform of the social management system, the social security system, the social service system, the social work system, the social security system, the social emergency system and the community management system. , The leading system of social management and the reform of the working mechanism.

The performance of social management refers to the achievements, efficiency, benefits and effects of social management subjects in the implementation and management of social management objects. Its connotation includes not only the overall performance of social 
management entities but also the performance of social management entities in the management process, that is, both Results performance and process performance or behavioral performance, the key lies in the results of performance. Scientific evaluation of the performance of social management is of great significance for innovating social management and improving the efficiency of social management. It is also of great significance in establishing a correct view of political achievements and promoting the innovation of the government and the reform of the cadre personnel system. As our country is currently establishing and improving a social management pattern of "government being responsible", the development of social organizations is not yet mature. Therefore, the performance of social management here refers mainly to the social management performance of the core government, which is actually the government One aspect of performance.

\section{Conclusion}

The social management of socialism with Chinese characteristics studied in this thesis is a comprehensive subject that spans two major disciplines: politics and society. The ultimate goal of this research is to probe into the issue of the development of socialist harmonious society and the development of socialist democracy with Chinese characteristics from the social management aspect. Based on this consideration, starting from the basic concepts and theories of social management, from the aspects of the social management of socialism with Chinese characteristics, the subject and object, the current problems and the underlying causes, and the perfecting strategy, this article analyzes the socialism with Chinese characteristics Social management carried out a macro-analysis, but did not follow the "management" logic or from the perspective of empirical sociology to discuss.

\section{References}

[1] Liu Guowu. Effectively promote the construction of network public opinion supervision system [J]. China Development Review. 2010 (11)

[2] Zhang Dechuan, Chen Xingyu. Analysis on the Intergovernmental Governance Pattern of Public Crisis [J]. Journal of Inner Mongolia Agricultural University (Social Science Edition). 2009 (06)

[3] Chen Wei, Zhang Lingzhi. Local government public crisis management of new ways [J]. Modern Commerce and Industry. 2009 (13)

[4] Ding Lieyun. Recovery and Reconstruction of Social Order in Crisis Management [J]. Journal of Huazhong Normal University (Humanities and Social Sciences). 2008 (05)

[5] Yao Jun, Huang Kai. On the Transition of the Management Function of Chinese Government Sports under the Condition of Market Economy - From Almighty Government to Limited Government [J] .Journal of Administration \& Law, 2008 (02)

[6] Xue Lan, Zhang Yang. Construction of a harmonious social mechanism to manage mass incidents [J]. Jiangsu Social Sciences. 2006 (04) 